\title{
Genetic diversity and evidence of recent demographic expansion in waterbird populations from the Brazilian Pantanal
}

\author{
Lopes, IF., Miño, CI. and Del Lama, SN.* \\ Departamento de Genética e Evolução, Universidade Federal de São Carlos - UFSCar, \\ Rodovia Washington Luis, Km 235, SP-310, CEP 13565-905, São Carlos, SP, Brazil \\ *e-mail: dsd1@power.ufscar.br \\ Received May 28, 2007 - Accepted August 28, 2007 - Distributed December 1, 2007
}

(With 2 figures)

\begin{abstract}
The present study determined nuclear and mitochondrial (mtDNA) levels of genetic variability and phylogeographic patterns in breeding populations of Roseate Spoonbill $(\mathrm{N}=57)$, Wood Stork $(\mathrm{N}=89)$, and Jabiru Stork $(\mathrm{N}=30)$, sampled in the Brazilian Pantanal. These species were selected since they are bioindicators of wetlands' health and are threatened in other parts of their distribution. As they are in close association with this ecosystem, they are appropriate for studying the effects of Pleistocene climatic changes on their demographic patterns. Levels of nuclear genetic diversity in Pantanal populations were not significantly different from those of other populations throughout the American continent, where they are considered threatened or of special concern. Reduced levels of mtDNA genetic diversity were observed in the Central American population of Jabiru Stork in comparison to the Pantanal population. Recent demographic expansion in the Pantanal was markedly evidenced by unimodal patterns of mismatch distribution and Fu's Fs neutrality test in these three species. We hypothesize that the average time of population expansion (between 30,843 and 14,233 years before present) is associated to responses of these birds' populations to paleoclimatic changes in these wetlands during the last glaciation period. We recommend special conservation efforts with the Jabiru Stork populations, a genetic monitoring program based on mtDNA, and an ecological characterization of these waterbirds species throughout their distribution range.
\end{abstract}

Keywords: waterbirds, Pantanal, populations, genetic variability.

\section{Diversidade genética e evidências de expansão demográfica recente nas populações de aves aquáticas do Pantanal brasileiro}

\begin{abstract}
Resumo
O presente estudo determinou níveis de variabilidade nuclear e mitocondrial (DNAmit) e padrões filogeográficos de populações reprodutivas de colhereiro $(\mathrm{N}=57)$, cabeça-seca $(\mathrm{N}=89)$ e tuiuiú $(\mathrm{N}=30)$ do Pantanal brasileiro. Estas espécies foram selecionadas porque são bioindicadoras da integridade das áreas alagáveis e se encontram ameaçadas em outras partes da sua área de distribuição. Devido à sua estreita associação com esse tipo de ecossistema, seu estudo permite verificar os efeitos das mudanças climáticas do Pleistoceno nos seus padrões demográficos. Níveis de diversidade genética nuclear nas populações pantaneiras não diferiram significativamente dos encontrados em outras populações ao longo do continente americano onde são consideradas ameaçadas ou como de especial interesse para conservação. Níveis reduzidos de variabilidade genética DNAmit foram observados nas populações de tuiuiú da América Central, quando comparadas às populações do Pantanal. A expansão demográfica recente das três espécies no Pantanal ficou marcadamente evidenciada pelos padrões unimodais da distribuição das diferenças pareadas e pelo teste de neutralidade de Fs de Fu. Hipotetizamos que o tempo médio de expansão populacional (entre 30.843 e 14.233 anos antes do presente) está associado as respostas destas populações de aves às mudanças climáticas ocorridas nas áreas alagáveis durante o último período de glaciação. Recomendamos, esforços especiais na conservação das populações do tuiuiú, um programa de monitoramento genético baseado no DNAmit e a caracterização ecológica dessas espécies de aves aquáticas ao longo de suas áreas de distribuição.
\end{abstract}

Palavras-chave: aves aquáticas, Pantanal, populações, variabilidade genética. 


\section{Introduction}

Wetlands are among the most threatened and highly biodiverse ecosystems in the world. The worldwide importance of these habitats is reflected in many inter-governmental treatises signed to ensure their protection and management, such as the Convention on Wetlands and the Ramsar Convention on Wetlands. The South American continent has the largest continuous inland wetland areas in the world, totalizing approximately $1,000,000 \mathrm{~km}^{2}$ (Neiff, 2001). Brazil alone possesses half of this area in its territory (Naranjo, 1995). The Pantanal region is one of the largest intra-continental wetlands, where many bird species have a major part of their total populations, while others are found in this region only during their reproductive period (Junk et al., 2006). From approximately 390 bird species recorded in Pantanal, 36\% are colonial breeders that depend on the gallery forest for breeding sites. This wetland harbors the greatest waterbird diversity of the South American continent (Scott and Carbonell, 1986; Junk et al., 2006). Waterbird populations have been used to monitor environmental changes in wetlands since their timing of reproductive activities and other population parameters respond directly to hydrologic fluctuations (Kushlan, 1993; Frederick and Ogden, 2003; Figueira et al., 2006).

Roseate Spoonbill (Platalea ajaja Linnaeus 1758), Wood Stork (Mycteria americana Linnaeus 1758), and Jabiru Stork (Jabiru mycteria Lichtenstein 1819) (Aves: Ciconiiformes) are waterbirds that are spatially co-distributed throughout Neotropical wetland areas from Southeastern Mexico to Central Argentina. These species are considered common and abundant in the Brazilian Pantanal, but are regionally threatened in other parts of their geographic range. For example, the Roseate Spoonbill population of the state of Florida (US) is considered of special concern for protection, as it underwent a profound bottleneck from 1890 to 1920 (Bjork and Powell, 1996; Florida Fish and Wildlife Conservation Commission, 2006). The Wood Stork has been listed as an endangered species in the US, after a population decline from 60,000 in the 1930 s to about 5,000 in 1978 (Ogden et al., 1987). The Jabiru Stork is classified as an "Appendix I" species under the Convention on International Trade in Endangered Species of Wild Fauna and Flora (CITES), and is considered threatened in Central America (Luthin, 1987; Stotz et al., 1996). Anthropogenic disturbances, such as habitat degradation and hunting, are among the main causes of past population declines of these species. Currently, climatic changes, e.g. global warming, have also been cited as important factors that affect several aspects of bird biology and can cause shifts in range (Crick, 2004; Parmesan, 2006).

In order to devise adequate conservation and management strategies for species that live in threatened habitats, it is important to incorporate a reliable understanding of their genetic diversity and demographic history (Frankham et al., 2002; Schwartz et al., 2007). Molecular markers can be used to track the demographic responses of populations to past climatic shifts and other historical processes (Templeton et al., 1995; Lessa et al., 2003), and to analyze the current intraspecific genetic variation in order to predict the impact of future climate changes on populations (Davis and Shaw, 2001). This approach is important for populations that are distributed over large areas and occur in both preserved and degraded regions. Nuclear microsatellite loci and mitochondrial DNA sequence data complement each other in revealing different aspects of genetic diversity within populations and can be useful in monitoring and management of conservation units (Brown et al., 2005).

Data from previous studies in Roseate Spoonbill (Santos, 2004; Miño and Del Lama, 2007), Wood Stork (Tomasulo-Seccomandi, 2004; Lopes et al., 2006), and Jabiru Stork (Lopes, unpublished data) were re-analyzed together in this study to compare levels of genetic variability and to infer demographic historic parameters among these waterbird populations that breed at the Brazilian Pantanal. We particularly addressed the following questions: i) Are the current levels of genetic diversity of Pantanal populations different from those of declining American populations of the same species?; ii) Are genetic data revealing demographic processes that populations have undergone in response to Pleistocene climatic events?; and iii) Which recommendations genetic information will support for conservation of waterbirds populations and wetlands?

\section{Material and Methods}

\subsection{Sample and DNA extractions}

Blood samples or growing feathers from nestlings and shed adult feathers were collected from Roseate Spoonbills, Wood Storks, and Jabiru Storks during five breeding seasons in the Pantanal region (1997, 1999, 2000, 2002, and 2003) (Figure 1). A total of 57 Roseate Spoonbill blood and feather samples were collected in four Pantanal colonies (Santos, 2004; Miño and Del Lama, 2007); Wood Stork blood samples from 89 nestlings were collected in eight Pantanal colonies (Tomasulo-Seccomandi, 2004; Lopes et al., 2006); and 30 Jabiru Stork samples were collected at three Pantanal regions, including 21 blood samples of unrelated chicks and nine feathers from dead nestlings $(\mathrm{N}=4)$ and from adults $(\mathrm{N}=5)$ found inside or below the nests (Lopes, unpublished data).

Total genomic DNA was extracted using Proteinase K digestion, followed by phenol/chloroform/isoamyl alcohol (PCI) isolation and ethanol precipitation (Sambrook and Russell, 2001). Total genomic DNA from molted adult feathers was extracted using the modified PCI protocol described in Miño (2006).

\subsection{Genotyping and sequencing}

Microsatellite loci. Fifty-seven Roseate Spoonbill samples were genotyped at four species-specific microsatellite loci (Aaju1, Aaju2, Aaju3, and Aaju5) described 


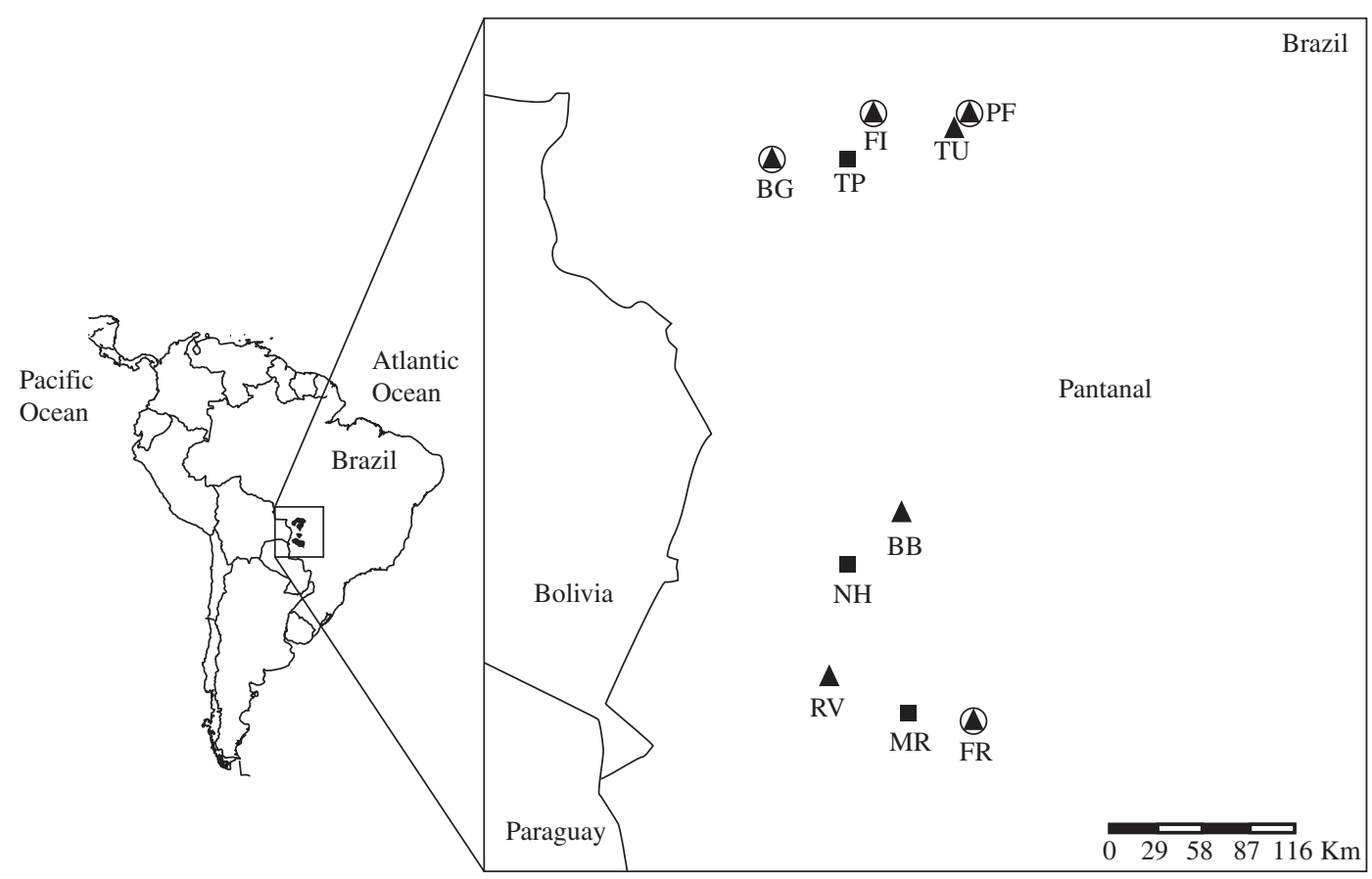

Figure 1. Roseate Spoonbill (circles) and Wood Stork (triangles) colonies, and Jabiru Stork (squares) locations sampled in the Pantanal area. Breeding colonies of Roseate Spoonbill and Wood Stork sampled: Baía de Gaíva (BG), Porto da Fazenda (PF), Tucum (TU), Fazenda Ipiranga (FI), Baía Bonita (BB), Fazenda Retirinho (FR), Rio Vermelho (RV); and regions of Jabiru Stork nests sampled: Transpantaneira (TP), Nhecolândia (NH), and Miranda (MR).

by Sawyer and Benjamin (2006), and at WS03 locus described for Wood Stork (Tomasulo-Seccomandi et al., 2003), following conditions described in Miño and Del Lama (2007). Polymerase chain reaction (PCR) products were sized in a MegaBACE ${ }^{\mathrm{TM}} 1000$ automatic sequencer, using the Gensize Rox 500 ladder as the internal standard (GE Healthcare). Results were analyzed using the GeneticProfiler $^{\circledR}$ software (GE Healthcare). Eighty-nine Pantanal Wood Stork samples were genotyped at ten specific microsatellite loci (WS03, WS08, WS09, WS13, WS14, WS18, WS19, WS20, WS23, WS24) following PCR conditions described in Tomasulo-Seccomandi et al. (2003). Thirty Jabiru Stork samples were genotyped at five heterologous microsatellite loci described for the Wood Stork (WS04, Van Den Bussche et al., 1999; WS13, WS16, WS18, and WS20, Tomasulo-Seccomandi et al., 2003). Alleles detected in heterologous loci in the Jabiru Storks sample showed similar sizes to those detected in the Wood Stork sample, and the differences in size between alleles were in the expected range, according to the number of repetitive units of each locus. PCR products from both stork species were automatically analyzed using an ABI 377-96 sequencer and the Genotyper program (PE Applied Biosystems).

Mitochondrial DNA. Partial mitochondrial DNA (mtDNA) control region fragments (Domain I or Domain III) were amplified and sequenced for the three species. A fragment of 483 base pairs (bp) of the mtDNA control region Domain I was amplified for 39 Roseate Spoonbill samples using the primers LPA-01 (5'-TATGTCAGGCGAGCATTCAA-3') and HCBS-1 (5'-TCCGACAAGCATTCACTAAAT-3') following PCR conditions described by Santos (2004). Fragments of 390/460 bp of the mtDNA control region Domain III were amplified and sequenced for 55 Wood Stork samples using the primers LCBS-1 (5' -TTTAGTGAATGCTTGTCGGA-3') and HCBS-1 according to conditions described by Lopes et al. (2006). PCR amplifications and sequencing of $549 \mathrm{bp}$ of the mtDNA control region Domain I were performed on 24 Pantanal Jabiru Stork samples using the primers WS-L36 (5'-TTCCTCCCAAATAACCATA-3') and WS-H601(5'CCTTGGCTGTGTGTACG-3') in a final volume of $50 \mu$ containing approximately $100 \mathrm{ng}$ of genomic DNA, $10 \mathrm{mM}$ Tris- $\mathrm{HCl} \mathrm{pH} 8.3,50 \mathrm{mM} \mathrm{KCl}, 0.25 \mathrm{mM}$ dNTPs, $0.5 \mathrm{mM}$ of each primer, $2.5 \mathrm{mg} / \mathrm{ml}$ bovine serum albumin (BSA), $2.5 \mathrm{mM} \mathrm{MgCl}_{2}$, and $1 \mathrm{U}$ of Taq DNA polymerase (Promega). The PCR cycling program was: 5 minutes at $94{ }^{\circ} \mathrm{C}$; five cycles of $20 \mathrm{~s}$ at $94^{\circ} \mathrm{C}, 20 \mathrm{~s}$ at $57^{\circ} \mathrm{C}$, and $20 \mathrm{~s}$ at $72{ }^{\circ} \mathrm{C} ; 21$ cycles of $20 \mathrm{~s}$ at $94{ }^{\circ} \mathrm{C}, 20 \mathrm{~s}$ at $57^{\circ} \mathrm{C}$ minus $0.5^{\circ} \mathrm{C}$ per cycle, and $30 \mathrm{~s}$ at $72{ }^{\circ} \mathrm{C} ; 10$ cycles of $20 \mathrm{~s}$ at $94{ }^{\circ} \mathrm{C}, 20 \mathrm{~s}$ at $46.5^{\circ} \mathrm{C}$, and $30 \mathrm{~s}$ at $72{ }^{\circ} \mathrm{C}$; and 10 minutes at $72{ }^{\circ} \mathrm{C}$.

\subsection{Data analyses}

Microsatellite loci. Standard population genetic analyses were conducted to quantify nuclear genetic diversity within the three analyzed species. Gene frequen- 
cies were calculated using Genepop v. 3.2 (Raymond and Rousset, 1995) and used to estimate other genetic variability parameters. Allelic richness was calculated using Fstat v. 2.9.3.2 (Goudet, 1995). Levels of genotypic diversity for each Roseate Spoonbill and Wood Stork breeding colony as well as each Jabiru Stork location were assessed by calculating observed $\left(\mathrm{H}_{\mathrm{O}}\right)$ and expected $\left(\mathrm{H}_{\mathrm{E}}\right)$ heterozygosity, using Genepop and Cervus v. 2.0 (Marshall et al., 1998). Diversity levels were compared among all colonies using the Student's t-test.

Mitochondrial DNA. Sequences were aligned using Bioedit (Hall, 1999) and visually verified. Haplotype diversity (h) and nucleotide diversity $(\pi)$ were computed using Arlequin (Schneider et al., 2000). Deviations from selective neutrality were tested by Fu's Fs (Fu, 1997) and Tajima's D (Tajima, 1989) approaches in Arlequin. Neutrality tests were used as an indication of recent population expansion when the null hypothesis of neutrality was rejected due to significant negative values $(\mathrm{p}<0.02$ for Fs and $\mathrm{p}<0.05$ for D). The DnaSP program (Rozas et al., 2003) was used to estimate Fu and Li's (1993) F* and $\mathrm{D}^{*}$ statistics, which are neutrality tests more sensitive to background selection. The distribution of pairwise nucleotide differences (mismatch distribution) was calculated as an additional test for demographic expansion (Rogers and Harpending, 1992), also using DnaSP. To test whether the observed distributions deviated significantly from those expected under the population expansion model, we computed the sum of square deviations (SSD) using the Arlequin program. The Rogers and Harpending (1992) model was used to calculate the time since population expansion by estimating Tau $(\tau), \theta_{0}$, and $\theta_{1}$ based on the mismatch distribution outputs from Arlequin. We converted the parameter $\tau$, calculated from the mismatch distribution, to estimate the time since the expansion $(\mathrm{t})$ using the equation $t=\tau / 2 \mathrm{u}$, where $\mathrm{u}$ is the mutation rate per sequence per generation (Rogers, 1995; Schneider and Excoffier, 1999). Time since expansion was estimated for each species using a range of mutation rates (2, 6 and $10 \%)$, to account for uncertainties in the rate of evolution of the avian mitochondrial control region (Pérez-Tris et al., 2004; Brito, 2005), and supposing a generation time of three years for the Roseate Spoonbill and four years for the Wood Stork and Jabiru Stork.

\section{Results}

\subsection{Nuclear and mtDNA diversity}

Table 1 summarizes microsatellite and mtDNA diversity in breeding populations of the three waterbird species sampled in the Brazilian Pantanal region. The Student's t- test showed non-significant $(p>0.05)$ differences in levels of genetic variability among colonies/ locations in these samples. The highest value of nuclear expected heterozygosity was detected in Porto da

Table 1. Genetic diversity based on microsatellite loci and mtDNA control region sequences for Roseate Spoonbill, Wood Stork, and Jabiru Stork populations in the Pantanal. Number of analyzed individuals (N), observed (Ho) and expected (He) heterozygosities, average number of alleles (A), average allelic richness (Rs), number of haplotypes (Hap), haplotype diversity (h), and nucleotide diversity $(\pi)$.

\begin{tabular}{|c|c|c|c|c|c|c|c|c|c|}
\hline \multirow{2}{*}{$\begin{array}{l}\text { Colony/Location } \\
\text { Roseate Spoonbill }\end{array}$} & \multicolumn{5}{|c|}{ Microsatellite loci } & \multicolumn{4}{|c|}{ MtDNA } \\
\hline & $\mathbf{N}$ & $\mathrm{He}$ & Ho & $\mathbf{A}$ & Rs & $\mathbf{N}$ & Hap & $\mathbf{h}$ & $\pi$ \\
\hline Baia de Gaíva & 20 & 0.649 & 0.624 & 5.2 & 3.044 & 14 & 8 & $0.824 \pm 0.098$ & $0.0050 \pm 0.003$ \\
\hline Fazenda Ipiranga & 11 & 0.624 & 0.499 & 3.4 & 2.695 & 4 & 3 & $0.500 \pm 0.265$ & $0.0010 \pm 0.001$ \\
\hline Porto da Fazenda & 8 & 0.711 & 0.712 & 3.4 & 3.010 & 6 & 4 & $0.800 \pm 0.004$ & $0.0050 \pm 0.004$ \\
\hline Fazenda Retirinho & 18 & 0.603 & 0.541 & 4.8 & 2.800 & 15 & 8 & $0.791 \pm 0.105$ & $0.0040 \pm 0.003$ \\
\hline Total & 57 & 0.646 & 0.594 & 4.2 & 2.89 & 39 & 15 & $0.753 \pm 0.071$ & $0.0040 \pm 0.002$ \\
\hline \multicolumn{10}{|l|}{ Wood Stork } \\
\hline Baia de Gaíva & 13 & 0.368 & 0.271 & 2.2 & 1.714 & 8 & 3 & $0.464 \pm 0.200$ & $0.0019 \pm 0.0018$ \\
\hline Fazenda Ipiranga & 10 & 0.337 & 0.280 & 2.1 & 1.684 & 7 & 2 & $0.476 \pm 0.171$ & $0.0050 \pm 0.0037$ \\
\hline Porto da Fazenda & 11 & 0.361 & 0.236 & 2.1 & 1.688 & 8 & 3 & $0.607 \pm 0.164$ & $0.0024 \pm 0.0021$ \\
\hline Tucum & 15 & 0.325 & 0.284 & 2.2 & 1.625 & 8 & 3 & $0.464 \pm 0.200$ & $0.0020 \pm 0.0018$ \\
\hline Baía Bonita & 12 & 0.315 & 0.187 & 2.2 & 1.621 & 8 & 4 & $0.643 \pm 0.184$ & $0.0026 \pm 0.0022$ \\
\hline Fazenda Retirinho & 13 & 0.386 & 0.237 & 2.5 & 1.755 & 8 & 3 & $0.464 \pm 0.200$ & $0.0019 \pm 0.0018$ \\
\hline Rio Vermelho & 15 & 0.378 & 0.302 & 2.5 & 1.749 & 8 & 8 & $1.000 \pm 0.062$ & $0.0074 \pm 0.0049$ \\
\hline Total & 89 & 0.358 & 0.259 & 2.9 & 2.234 & 55 & 17 & $0.619 \pm 0.077$ & $0.0039 \pm 0.0026$ \\
\hline \multicolumn{10}{|l|}{ Jabiru Stork } \\
\hline Transpantaneira & 13 & 0.482 & 0.440 & 3.2 & 2.649 & 11 & 6 & $0.855 \pm 0.085$ & $0.0036 \pm 0.0007$ \\
\hline Miranda & 8 & 0.570 & 0.415 & 3.2 & 3.019 & 5 & 4 & $0.900 \pm 0.161$ & $0.0050 \pm 0.0012$ \\
\hline Nhecolândia & 9 & 0.497 & 0.555 & 2.8 & 2.612 & 8 & 7 & $0.964 \pm 0.077$ & $0.0056 \pm 0.0011$ \\
\hline Total & 30 & 0.549 & 0.476 & 3.4 & 2.772 & 24 & 12 & $0.906 \pm 0.038$ & $0.0043 \pm 0.0005$ \\
\hline
\end{tabular}


Fazenda (0.711) for the Roseate Spoonbill; in Fazenda Retirinho (0.386) and Rio Vermelho (0.378) for the Wood Stork; and in Miranda (0.570) for the Jabiru Stork. Analyses of mtDNA control region sequences revealed the highest nucleotide diversity values in Baia de Gaíva and Porto da Fazenda colonies (0.005) for the Roseate Spoonbill; in Rio Vermelho (0.007) for the Wood Stork; and in Nhecolândia (0.006) for the Jabiru Stork.

\subsection{Demographic history}

The analysis of mtDNA haplotype distribution allowed us to identify the presence of single haplotypes that are common to all colonies/locations in these three studied species (data not shown). An association of one common haplotype with others in lower frequencies or private haplotypes is a pattern frequently attributed to populations that have undergone recent range expansion (Slatkin and Hudson, 1991; Rogers and Harpending, 1992). All studied populations showed unimodal patterns of mismatch distribution curves, as expected in cases of population expansion (Figure 2). None of the sums of squared deviations (SSD) of mismatch distribution was significant, indicating that the curves fit the sudden expansion model tested (Figure 2).

Neutrality tests applied to search for additional demographic signs of population expansion are also in concordance with the above pattern. The measure of Fu's Fs statistic based on the control region sequences revealed values significantly different from zero in all analyzed species, suggesting a recent expansion in the Pantanal. Similarly, Tajima's D test was significantly negative for the Roseate Spoonbill and Wood Stork, but positive and non-significant for Jabiru Stork populations. Non-significant values in $\mathrm{D}^{*}$ and $\mathrm{F}^{*}$ tests combined with a significant $\mathrm{Fs}$ have been interpreted by $\mathrm{Fu}$ (1997) as evidence of the absence of background selection, therefore supporting indications of demographic expansions. Fu and Li's $\mathrm{D}^{*}$ and $\mathrm{F}^{*}$ tests presented significant departure from neutrality for both the Roseate Spoonbill and Wood Stork, thus indicating the possible occurrence of background selection. In Jabiru Stork samples, the deviation from neutrality was not explained by background selection, as evidenced by the nonsignificant values of $\mathrm{Fu}$ and $\mathrm{Li}$ 's $\mathrm{D}^{*}$ and $\mathrm{F}^{*}$ tests.

Based on our estimated values of $\tau$, the average time since the demographic expansion for these waterbird species in the Pantanal region ranged from approximately 30,843 years before the present (ybp) (Wood Stork) to 14,233 ybp (Jabiru Stork) (Table 2). Although these dates were estimated based on different portions of the mtDNA control region (Domain I for the Roseate Spoonbill and Jabiru Stork; Domain III for the Wood Stork), the $\tau$ values were not significantly different from each other due to the large $95 \%$ confidence intervals around the point estimates (Table 2).

\section{Discussion}

This is the first genetic evaluation of co-distributed Pantanal waterbird populations combining mtDNA sequences and microsatellite loci data. Populations were
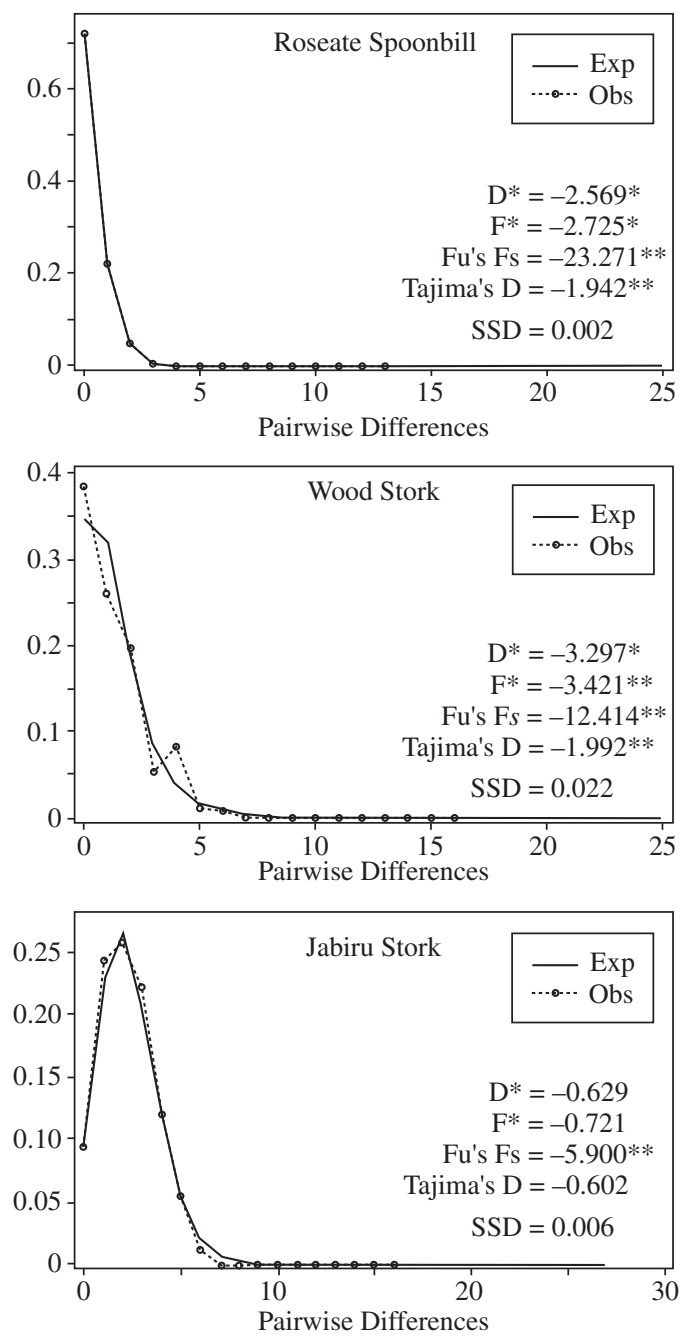

Figure 2. Observed and expected mismatch distribution under population expansion model, Fu and Li's D* and $\mathrm{F}^{*}$, Fu's Fs, and Tajima's D neutrality tests, and the sums of squared deviations (SSD) for Roseate Spoonbill, Wood Stork, and Jabiru Stork mtDNA control region sequences. $(* 0.01<\mathrm{p}<0.05 ; * * \mathrm{p} \leq 8804 ; 0.01)$

characterized in terms of genetic diversity and were compared to other threatened breeding populations throughout their distribution in the Americas. This study also expands the scarce data on historical demographic patterns exhibited by natural populations inhabiting Neotropical areas.

\subsection{Genetic variability}

The highest levels of diversity evaluated through nuclear and mitochondrial data were found in the same Pantanal colonies for the Roseate Spoonbill (Porto da Fazenda) and Wood Stork (Fazenda Retirinho and Rio Vermelho). It is worth noting that Porto da Fazenda is a stable colony and has been recorded over the last 80 years (Bouton et al., 2005) and Rio Vermelho is considered the largest colony in the southern Pantanal (2,500 breeding 
Table 2. Parameters for Roseate Spoonbill, Wood Stork and Jabiru Stork Pantanal populations obtained from mismatch distribution analyses: age of expansion in units of mutational time $(\tau)\left(95 \%\right.$ confidence interval), population size before $\left(\theta_{0}\right)$ and after $\left(\theta_{1}\right)$ the expansion in units of mutational time, and age of expansion (t) in years B. P. calculated using $2 \%, 6 \%$, and $10 \%$ mutation rate and the average (Ave).

\begin{tabular}{clll}
\hline Parameters & \multicolumn{1}{c}{ Roseate Spoonbill } & \multicolumn{1}{c}{ Wood Stork } & \multicolumn{1}{c}{ Jabiru Stork } \\
\hline$\tau$ & $2.924(0.689-6.293)$ & $3.756(0.516-9.818)$ & $2.317(0.712-3.211)$ \\
$\theta_{0}$ & 0.003 & 0.005 & 0.000 \\
$\theta_{1}$ & 3.619 & 1.820 & 2760.000 \\
$\mathrm{t}$ & $2 \%: 50,448 ; 6 \%: 16,816 ;$ & $2 \%: 60,347 ; 6 \%: 20,115 ;$ & $2 \%: 27,848 ; 6 \%: 9,283 ;$ \\
& $10 \%: 10,089 ;$ Ave: 25,733 & $10 \%: 12,069 ;$ Ave: 30,843 & $10 \%: 5,570 ;$ Ave: 14,233 \\
\hline
\end{tabular}

pairs; EJ Marques, personal communication). Diversity levels revealed contrasting patterns for microsatellite loci and mtDNA in Jabiru Stork samples collected at the three locations, but increasing the sample size and/ or adding locations may change this picture. Innovative non-invasive sampling strategies, e. g. collection of molted feathers, will also help genetically monitor populations as they involve a lower sampling effort and can be performed by a licensed non-scientist with access to breeding colonies and nests.

Microsatellite data revealed that Pantanal samples presented levels of genetic variability similar to those of threatened or of concern populations of the three species. Nuclear variability of the Roseate Spoonbill population in the Pantanal was not significantly different from that of a sample of 51 wild individuals caught in Florida (US) $(\mathrm{Ho}=0.667 ; \mathrm{He}=0.649)$, where these species had undergone a well-documented demographic reduction (Sawyer, 2002; Miño and Del Lama, 2007). Similarly, Wood Stork population analyses revealed no statistical differences in genetic diversity between the threatened southeastern US breeding populations and those of the Pantanal (Tomasulo-Seccomandi, 2004). The lack of difference in genetic variability levels between Wood Stork samples collected in these two areas was also reported in previous studies based on allozymes and four different microsatellite loci (Del Lama et al., 2002; Rocha et al., 2004). Expansions of Jabiru Stork variability analyses indicated that the Pantanal samples exhibited no significant differences when compared to both northern South American population (Venezuela and Guyana) or to the endangered Central American (Belize) population (Lopes et al., unpublished data). These similarities in levels of genetic diversity between the Pantanal and the threatened populations seem to indicate that the demographic declines reported for populations outside the Pantanal were not strong enough to affect nuclear genetic diversity (Lopes et al., unpublished data). Alternatively, these results can also be explained by the existence of an ongoing gene flow among the analyzed areas or as a result of a recent demographic expansion of these species in the studied areas from a single ancestral population.

A mtDNA analysis of Jabiru Stork populations, including sequences from Domain I of the control region and the ND2 gene, revealed that variability indices in Jabiru Storks samples from Belize were zero, while a higher but non significant level of diversity was observed in the Pantanal samples $\left(\mathrm{h}_{\text {mean }}=0.906, \pi_{\text {mean }}=0.004\right)$ (Lopes et al., unpublished data). This lack of mtDNA diversity likely results from the small population size combined with the recent decrease and extirpation of the Jabiru Stork from several Central American areas (Lopes et al., unpublished data). As microsatellite markers show bi-parental inheritance and higher effective population sizes in comparison to mtDNA, they are less sensitive than mtDNA data in revealing declines in the levels of variability (Frankham et al., 2002; Avise, 2004; Friesen et al., 2007). Analyses of genetic diversity using mtDNA were restricted to the Pantanal for the Roseate Spoonbill and Wood Stork populations (Santos, 2004; Lopes et al., 2006). Thus, in order to evaluate the genetic status of other breeding populations, especially endangered ones, the expansion of these analyses must be considered using mtDNA genetic diversity in populations of both species throughout their American distribution. These future studies will either accept or refuse the hypothesis that a decrease in diversity is really occurring or it is not be detected by nuclear markers.

\subsection{Demographic history}

MtDNA partial control region sequences (Domain I or III) revealed a similar pattern of demographic expansion in the studied species: Roseate Spoonbill (Santos, 2004), Wood Stork (Lopes et al., 2006), and Jabiru Stork (Lopes et al., unpublished data). The recent demographic expansion of these populations in the Pantanal was indicated by the significant negative Fu's Fs values, the unimodal mismatch distribution curves (Figure 2), values of population size before $\left(\theta_{0}\right)$ and after $\left(\theta_{1}\right)$ demographic expansion (Table 2), and the star shape of the haplotype networks (data not shown).

According to our results, the Wood Stork expanded first in the Pantanal area $(30,843 \mathrm{ybp})$, followed by the Roseate Spoonbill (25,733 ybp), and more recently by the Jabiru Stork (14,233 ybp), although the differences among the average times since demographic expansion were non-significant. The earlier expansion of the Wood Stork and Roseate Spoonbill in the Pantanal is an expected fact, considering their migrating behavior. Migratory species such as Roseate Spoonbill and Wood Stork exhibit patterns of movements that can facilitate exploration of new areas suitable for breeding. Resident 
and phylopatric species such as the Jabiru Stork may have delayed migration to other habitats, thus reaching the Pantanal area more recently. We can also suppose that when environmental changes were a concern, species that have a broader distribution range, such as the Roseate Spoonbill and Wood Stork, may have moved to suitable areas for breeding and foraging more easily than species that occur in more restricted geographic ranges, such as the Jabiru Stork. Alternatively, this difference may be due to differential reproductive rates (or population growth rates) of the three species, but there are no ecological studies addressing these aspects for these species, impairing conclusive inferences.

These movement patterns hypothesized during the glacial period can help us to understand and predict the responses of bird populations to current climate changes. Crick (2004) discussed how recent climate changes may affect the viability of the habitats that birds use, changing the timing and abundance of their food supplies and other resources. The author stated that a loss of habitat or decline in habitat quality can produce changes in the range of the species, with expansion or contraction in response to climate changes. As the species analyzed in our study require the same habitats for foraging and breeding, their past movement patterns may have been similar, as a consequence of their ecological requirements.

Junk (2003) stated that paleoclimatic events caused dramatic changes in wetland areas and in the biodiversity that these ecosystems support, particularly in the Alto Araguaia and the Pantanal regions, which depend on rainwater for the seasonal flooding to occur. The determination of phylogeographic patterns of co-distributed taxa through mtDNA studies allows us to infer past population demographic alterations (Avise, 2000). As the species studied in the present work are wetland dependent, information on levels of humidity in the Pantanal region during and after the last Pleistocene glaciation is essential to interpret their historical demographic expansions. Although paleontologists generally agree that the South America was characterized by cooler temperatures during the glacial periods (on average 4 to $12{ }^{\circ} \mathrm{C}$ lower than the current temperature), questions remain unanswered regarding humidity (Clapperton, 1993; Colinvaux et al., 2000). Clapperton (1993) proposed that the Pantanal region exhibited an arid climate during the last glacial period (25,000-15,000 ybp). More recent studies performed in areas near the Pantanal have identified a much humid weather than the previously suggested (de Oliveira, 1992; Ledru, 1993; Ferraz-Vicentini and Salgado-Laboriau, 1996; Assine and Soares, 2004). Our expansion time estimates suggest that the studied species may have been exploring the area before the Holocene period, following an increase in moisture between 32,000 and 20,000 years ago in central Brazil (Ledru, 1993; SalgadoLaboriau et al., 1997). Our data are also in concordance with the pattern of demographic expansion reported for a species with similar habitat requirements, the marsh deer (Blastocerus dichotomus Illiger, 1815), in the same period and region (Marquez et al., 2006).

\subsection{Conservation implications}

Conservation strategies in wetlands are more easily defined when current levels and distribution of genetic diversity in waterbird populations as well as their historical phylogeographic patterns are established.

Similar levels of nuclear diversity were found when Roseate Spoonbill and Wood Stork populations in the Pantanal were compared to populations established throughout the Americas. Diversity levels evaluated in Pantanal populations using nuclear markers were unable to identify a specific region within the Pantanal with significantly more diversity than others. Lack of genetic variability in Central American Jabiru Stork populations was evidenced in relation to the Pantanal using mtDNA markers. Jabiru Stork data revealed that Pantanal populations may be a source of genetic diversity and could be used in a future re-colonization of other areas of the continent. Based on the Jabiru Stork data, we recommend an expansion of this comparative analysis, using mtDNA markers in Wood Stork and Roseate Spoonbill populations from other Brazilian regions and throughout the Americas. This approach can direct the application of Brazilian Environmental Law No 5,197 (January 3rd, 1967) to regions that were identified as conservation priorities among all bird breeding sites within the country.

Responses to climate pressures in the past can be used to predict which species are more susceptible to ongoing climate changes. The migratory behavior and the wider distribution range of the Wood Stork and Roseate Spoonbill may have helped them to find new places that were suitable for reproducing after the last glaciation. On the other hand, the Jabiru Stork, which is considered a resident species and shows site fidelity, may have delayed its expansion. Signs of demographic expansion and average timing since expansion for these species suggest a higher susceptibility of the Jabiru Stork to climatic changes.

Based on this research, we recommend that Brazilian government agencies start a monitoring program of waterbird populations in order to gather information on ecological and genetic parameters before making decisions regarding wetland conservation. This approach will be essential to preserve the evolutionary potential of waterbird populations inhabiting wetlands as well as to conserve the ecosystems.

Acknowledgments - The authors are grateful to AM. TomasuloSeccomandi, MH. Santos, T. Glenn, and SM. Haig for sharing useful information. We are grateful to CEMAVE/IBAMA for permission to handle the birds and collect biological material. We wish to thank the farm owners that gave us access to the colonies (J.J.Dittmar, J. Lousano, O.C. Cunha, T. Proença, R. Klabin, and J.Ricardo). We kindly acknowledge the useful suggestions and comments made by the anonymous reviewers. This work was financially supported by FAPESP (98/06160-8, 99/16359-6, 04/15205-8, 04/09321-5), CNPq (473760/2004-5, 140768/2002-5, 32188/2004-0), CAPES (BEX: 2925/03), and PPG-GEv-UFSCar. 


\section{References}

ASSINE, ML. and SOARES, PC., 2004. Quaternary of the Pantanal, west-central Brazil. Quatern. Int., vol. 114, no. 1, p. 23-34.

AVISE, JC., 2000. Phylogeography: the history of formation of species. Cambridge, Harvard University Press. 447p.

-, 2004. Molecular Markers, Natural History and Evolution, Second Edition. Sunderland, Massachusetts, Sinauer Associates, Inc. Publishers, 684p.

BJORK, RD., and POWELL, GVN., 1996. Roseate Spoonbill, In RODGERS, JA., KALE, HW. and SMITH, HT. (eds.), Rare and endangered biota of Florida: Volume 5: birds. University of Florida Press, Gainesville, Florida. p. 295-308.

BOUTON, SN., FREDERICK, PC., ROCHA, CD., BARBOSA DOS SANTOS, AT. and BOUTON, TC., 2005. Effects of Tourist Disturbance on Wood Stork Nesting Success and Breeding Behavior in the Brazilian Pantanal. Waterbirds, vol. 28, no. 4, p. 487-497.

BRITO, PH., 2005. The influence of Pleistocene glacial refugia on tawny owl genetic diversity and phylogeography in western Europe. Mol. Ecol., vol. 40, no.10, p. 3077-3094.

BROWN, LM., RAMEY, RR., TAMBURINI, B. and GAVIN, TA., 2005. Population structure and mitochondrial DNA variation in sedentary Neotropical birds isolated by forest fragmentation. Conserv. Genet., vol. 5, no. 6, p. 743-757.

CLAPPERTON, CM., 1993. Nature of environmental changes in South America at last glacial maximum. Palaeogeogr., Palaeocl., vol. 101, no. 3-4, p. 189-208.

COLINVAUX, PA., DE OLIVEIRA, PE. and BUSH, MB., 2000. Amazonian and Neotropical plant communities on glacial time-scales: the failure of the aridity and refuge hypothesis. Quarter. Rev. Sci., vol. 19, p. 141-169.

CRICK, HQP., 2004. The impact of climate change on birds. Ibis, vol. 146, no. S1, p. 48-56.

DAVIS, MB. and SHAW, RG., 2001. Range shifts and adaptive responses to quaternary climate change. Science, vol. 292, no. 5517, p. 673-79.

DE OLIVEIRA, PE., 1992. A palynological record of late Quaternary vegetational and climatic change in southeastern Brazil. 238p. (PhD Thesis) - Ohio State University, USA.

DEL LAMA, SN., LOPES, IF. and DEL LAMA, MA., 2002. Genetic variability and level of differentiation among Brazilian Wood Stork populations. Biochem. Genet., vol. 40, no. 3-4, p. 87-99.

FERRAZ-VICENTINI, KR. and SALGADO-LABOURIAU, ML., 1996. Palynological analysis of a palm swam in central Brazil. J. S. Am. Earth. Sci., vol. 9, no. 3, p. 207-219.

FIGUEIRA, JEC., CINTRA, R., VIANA, LR. and YAMASHITA, C., 2006. Spatial and temporal patterns of bird species diversity in the Pantanal of Mato Grosso, Brazil: implications for conservation. Braz. J. Biol., vol. 66, no. 2a, p. 393-404.

FLORIDA FISH AND WILDLIFE CONSERVATION COMMISSION, 2006. Florida's endangered species, threatened species and species of special concern. Official List. http://myfwc.com/imperiledspecies/pdf/Threatened-andEndangered-Species-2006.pdf [Access: November 7, 2007].
FRANKHAM, R., BALLOU, JD. and BRISCOE, DA., 2002. Introduction to conservation genetics. Cambridge, UK, Cambridge University Press. 617p.

FREDERICK, PC. and OGDEN, JC., 2003. Philopatry and nomadism: contrasting long-term movement behavior and population dynamics of White Ibises and Wood Storks. Colon. Waterbird., vol. 20, no. 2, p. 316-323.

FRIESEN, VL., BURG, TM. and MCCOY, KD., 2007. Mechanisms of population differentiation in seabirds. Mol. Ecol., vol. 16, n. 9, p. 1765-1785.

FU, YX., 1997. Statistical tests of neutrality of mutations against population growth, hitchhiking and background selection. Genetics, vol. 147, p. 915-925.

FU, YX. and LI., WH., 1993. Statistical tests on neutrality of mutations. Genetics, vol. 133, p. 693-709.

GOUDET, J., 1995. Fstat v. 1.2: a computer program to calculate F-statistics. J. Hered., vol. 86, no. 6, p. 485-486.

HALL, TA., 1999. Bioedit: a user-friendly biological sequence alignment editor and analysis program for windows 95/98/NT. Nucl. Acids Symp. Ser., vol. 41, p. 95-98.

JUNK, WJ., 2003. Tropical/subtropical wetland biodiversity: status of knowledge, threats and sustainable management. In BERNARD, T., MOSPELE, K. and RAMBERG, L. (orgs.). Environmental monitoring of tropical and subtropical wetlands. Maun, Okavango Report Series, vol. 1 - Harry Oppenheimer Okavango Research Centre and University of Botswana. p. $45-69$.

JUNK, WJ., NUNES DA CUNHA. K., WANTZEN, KM., PETERMANN, P., STRUSSMANN, C., MARQUES. MI. and ADIS, J., 2006. Biodiversity and its conservation in the Pantanal of Mato Grosso. Brazil. Aquat. Sci., vol. 68, no. 3, p. 278-309.

KUSHLAN, JA., 1993. Colonial waterbirds as bioindicators of environmental change. Colon. Waterbird., vol. 16, no. 2, p. 223-251.

LEDRU, MP., 1993. Late Quaternary environmental and climatic changes in Central Brazil. Quaternary Res., vol. 39, p. $90-98$.

LESSA, EP., COOK, JA. and PATTON, JL., 2003. Genetic footprints of demographic expansion in North America, but not Amazonia, during the Late Quaternary. P. Natl. Acad. Sci. USA, vol. 100, no. 18, p. 10331-10334.

LOPES, IF., BRITO, RA., HENRIQUE-SILVA, F. and DEL LAMA, SN., 2006. Demographic history of wood stork (Mycteria americana) Brazilian Pantanal colonies revealed by mitochondrial DNA analysis. Genet. Mol. Biol., vol. 29, no. 2, p. 241-250.

LUTHIN, CS., 1987. Status of and conservation priorities for the world's stork species. Colon. Waterbird., vol. 10, no. 2, p. $181-202$.

MARSHALL, TC., SLATE, J., KRUUK, L. and PEMBERTON, JM., 1998. Statistical confidence for likelihood-based paternity inference in natural populations. Mol. Ecol., vol. 7, no. 5, p. 639-655.

MARQUEZ, A., MALDONADO, JE., GONZALEZ, S., BECCACECI, MD., GARCIA, JE. and DUARTE, JMB, 2006. Phylogeography and Pleistocene demographic history of the endangered marsh deer (Blastocerus dichotomus) from the Río de la Plata Basin. Conserv. Genet., vol. 7, no. 4, p. 563-575. 
MIÑO, CI. 2006. Estrutura Genética e Relações de Parentesco em Populações de Colhereiro (Platalea ajaja, Aves: Threskiornithidae). 97p. (Dissertação de Mestrado) - UFSCar, São Carlos, SP.

MIÑO, CI. and DEL LAMA, SN., 2007. Genetic structure in Brazilian breeding colonies of the Roseate Spoonbill (Platalea ajaja, Aves: Threskiornithidae). Genet. Mol. Res., vol. 6, p. 238-247.

NARANJO, LG., 1995. An evaluation of the first inventory of South American wetlands. Vegetatio, vol. 118, no. 1-2, p. 125-129.

NEIFF, J., 2001. Diversity in some tropical wetland systems of South America. In GOPAL, B., JUNK, W. and DAVIS, J. (eds.). Biodiversity in Wetlands: Assessment, Function and Conservation Vol. 2. Backhuys Publishers, Leiden, The Netherlands, p. 157-186.

OGDEN, JC., MCCRIMMON JR., DA., BANCROFT, GT. and PATTY, BW., 1987. Breeding population of Wood Stork (Mycteria americana) in southeastern United States. Condor, vol. 89 , n. 4 , p. $752-759$.

PARMESAN, C., 2006. Ecological and evolutionary responses to recent climate change. Annu. Rev. Ecol. Evol. S., vol. 37, p. 637-669.

PÉREZ-TRIS, J., BENSCH, S., CARBONELL, R., HELBIG, AJ. and TELLERÍA, JS., 2004. Historical diversification of migration patterns in a passerine bird. Evolution, vol. 58, no. 8, p. $1819-1832$.

RAYMOND, M. and ROUSSET, F., 1995. Genepop version 1.2: population genetics software for exact tests and ecumenicism. $J$. Hered., vol. 86, no. 3, p. 248-249.

ROCHA, CD., DEL LAMA, SN. and REGITANO, LCA., 2004. Lack of genetic structuring among tropical Brazilian Wood Stork populations and low genetic differentiation from North American populations. Biotropica, vol. 36, no. 2, p. 248-258.

ROGERS, AR., 1995. Genetic evidence for a Pleistocene population explosion. Evolution, vol. 49, no. 4, p. 608-615.

ROGERS, AR. and HARPENDING, H., 1992. Population growth makes waves in the distribution of pairwise genetic differences. Mol. Biol. Evol., vol. 9, no. 3, p. 552-569.

ROZAS, J., SANCHEZ-DELBARRIO, J., MESSEGUER, X. and ROZAS, R., 2003. Dnasp: DNA polymorphism analyses by the coalescent and other methods. Bioinformatics, vol. 19, p. 2496-2497.

SALGADO-LABOURIAU, ML., CASSETI, V. and FERRAZVICENTINI. KR., 1997. Late Quaternary vegetational and climatic changes in cerrado and palm swamp from Central Brazil. Palaeogeogr. Palaeocl., vol. 128, no. 1, p. 215-226.

SAMBROOK, J. and RUSSELL, DW., 2001. Molecular cloning, a laboratory manual. $3^{\text {rd }}$ ed. Vol 1. New York, Cold Spring Harbor Laboratory Press.

SANTOS, MH., 2004. Estudo de haplótipos do DNA mitochondrial de colhereiros (Aves, Ordem Ciconiiformes, Platalea ajaja). 79p. (Dissertação de Mestrado) - UFSCar, São Carlos, SP.
SAWYER, GM., 2002. DNA profiling of captive Roseate Spoonbill (Ajaia ajaja) populations as a mechanism of determining lineage in colonial nesting birds. 356p. (PhD Dissertation) - University of North Texas, USA.

SAWYER, GM. and BENJAMIN, RC., 2006. Isolation and characterization of microsatellite loci for parentage assessment in captive populations of Roseate spoonbill (Ajaia ajaja). Mol. Ecol. Notes, vol. 6, no. 3, p. 677-679.

SCHNEIDER, S. and EXCOFFIER, L., 1999. Estimation of demographic parameters from the distribution of pairwise differences when the mutation rates vary among sites: Application to human mitochondrial DNA. Genetics, vol. 152, p. $1079-1089$.

SCHNEIDER, S., ROESSLI, D. and EXCOFFIER, L., 2000. Arlequin v. 2000: A software for population genetics analysis. Switzerland, Genetics and Biometry Laboratory, University of Geneva. http://anthro.unige.ch/software/arlequin/ [Access: November 7, 2007].

SCHWARTZ, MK, LUIKART, G. and WAPLES, RS., 2007. Genetic monitoring as a promising tool for conservation and management. Trends Ecol. Evol., vol. 22, no. 1, p. 25-33.

SCOTT, D. and CARBONELL, M., 1986. A Directory of Neotropical Wetlands. Cambridge, UK, IUCN Conservation Monitoring Centre. 669p.

SLATKIN, M. and HUDSON, RR., 1991. Pairwise comparisons of mitochondrial DNA sequences in stable and exponentially growing populations. Genetics, vol. 123, p. 603-613.

STOTZ, DF., FITZPATRICK, JW., PARKER, TA., and MOSKOVITS, DK., 1996. Neotropical birds: ecology and conservation. Chicago, USA, University of Chicago Press. 700p.

TAJIMA, H., 1989, Statistical method for testing the neutral mutation hypothesis by DNA polymorphism. Genetics, vol. 123, p. 585-595.

TEMPlETON, AR., ROUTMAN, E. and PHILIPS, CA., 1995. Separating population structure from population history - a cladistic analysis of the geographical distribution of mitochondrial haplotypes in the Tiger Salamander Ambystoma tigrinum. Genetics, vol. 140, p. 767-782.

TOMASUlO-SECCOMANDI, AM., 2004. Populações de Mycteria americana (Aves; Ciconiiformes) da América do Norte e do Pantanal Brasileiro: estruturação genética, razão sexual e assimetria flutuante. 92p. (Tese de Doutorado) - UFSCar, São Carlos, SP.

TOMASULO-SECCOMANDI, AM., SCHABLE, N., BRYAN, A., BRISBIN, I., DEL LAMA., SN. and GLENN, TC., 2003. Development of microsatellite DNA loci from the wood stork (Aves, Ciconiidae, Mycteria americana). Mol. Ecol. Notes, vol. 3 , no. 4, p. 563-566.

VAN DEN BUSSCHE, RA., HARMON, SA., BAKER, RJ., BRYAN JR., AL., RODGERS JR., JA., HARRIS, MJ. and LEHR BRISBIN JR., I., 1999. Low levels of genetic variability in North American populations of the Wood Stork (Mycteria americana). Auk, vol. 16, no. 4, p. 1083-1092. 
